\title{
Vertical size distribution of phytoplankton in the western Mediterranean Sea during early summer
}

\author{
P. Raimbault, I. Taupier-Letage, M. Rodier \\ Centre d'Océanologie de Marseille, Faculté des Sciences de Luminy, Case 901, F-13288 Marseille, France
}

\begin{abstract}
Size fractions of chlorophyll $a(\mathrm{chl} a)<10,<3$ and $<1 \mu \mathrm{m}$ were measured by fluorimetry in 2 areas of the Mediterranean Sea: the Ligurian Sea and the Algerian Basin. Most of the particulate matter containing chl $a$ in the photic zone was very small: 80 to $100 \%$ passed through a $10 \mu \mathrm{m}$ mesh net; 30 to $80 \%$ and 20 to $60 \%$ passed through 3 and $1 \mu \mathrm{m}$ nuclepore membranes respectively. The chlorophyll biomass of each size class was maximum in the surface or subsurface chlorophyll maximum layer. During the summer stratification, the relative importance of the $<10 \mu \mathrm{m}$ fraction in the water column, calculated as percentage of chlorophyll $<10 \mu \mathrm{m}$ versus total chlorophyll, did not change; but the percentages of the $<3$ and $<1 \mu \mathrm{m}$ fractions were maximum at the top and at the bottom of the photic zone and minimum in the chl a maximum layer, where phytoplankton $>3 \mu \mathrm{m}$ represented more than $60 \%$ of the chl a biomass. A comparison with literature data from tropical waters shows significant differences for the distribution of the $<1 \mu \mathrm{m}$ fraction, but not for the $<3$ and $<10 \mu \mathrm{m}$ fractions.
\end{abstract}

\section{INTRODUCTION}

Very small phytoplankton $(<3 \mu \mathrm{m})$ account for an important fraction of autotrophic biomass in the sea. The predominance of small autotrophic organisms seems to be a distinguishing feature of warm oligotrophic oceans where the $<1 \mu \mathrm{m}$ and $<3 \mu \mathrm{m}$ fractions may represent more than $50 \%$ of the total phytoplankton biomass in terms of either chlorophyll a (Bienfang \& Szyper 1981, Bienfang \& Takahashi 1983, Herbland et al. 1985), carbon (Herbland \& Lebouteiller 1981, Furuya \& Marumo 1983a, Takahashi et al. 1985), or cell concentrations (Waterbury et al. 1979, Murphy \& Haugen 1985). Small phytoplankton can be responsible for the majority of primary production in tropical oceanic waters (Gieskes et al. 1979, Li et al. 1983, Platt et al. 1983, Takahashi \& Bienfang 1983). Recent investigations, however, have revealed significant abundance and production of phytoplankton $<3 \mu \mathrm{m}$ in temperate waters as well as in the North Atlantic (Joint \& Pomeroy 1983, Joint et al. 1986) and in the Mediterranean Sea (Berman et al. 1984, Azov 1986, Rassoulzadegan et al. 1987).

This study investigated some aspects of the occurrence and abundance of different size classes of chlorophyll-containing particles $(<10,<3$ and $<1 \mu \mathrm{m})$ in the western Mediterranean Sea, using filtration sizing and chlorophyll measurements. This method has previously been used to describe chlorophyll distribution among various size classes of phytoplankton in tropical regions (Saijo \& Takesue 1965, Gieskes et al. 1979, Bienfang 1984, 1985, Herbland et al. 1985). Our purpose is to report results of the vertical size distribution of chlorophyll throughout the euphotic zone during the seasonal stratification in early summer, in relation to the position of the chlorophyll maximum. A comparison is made with the vertical distribution of phytoplankton observed in tropical regions permanently underlain by a strong thermocline.

\section{MATERIALS AND METHODS}

Samples were taken from 2 study areas in the western Mediterranean Sea (Fig. 1): in the Ligurian Sea during the Prolig II cruise (May-June 1985) on the RV 'Noroit' and in the Algerian Basin during the Mediprod V cruise (May-June 1986) on the RV 'Suroit'.

Seawater samples were collected with 51 Niskin bottles on a rosette fixed to the CTD system. Sampling depths ( 4 to 6 in the photic zone) were chosen from temperature and salinity profiles recorded from CTD casts. Additional sampling was performed with a submersible pumping system for vertical profiling (Prieur et al. 1988).

Nutrients (nitrate, nitrite, silicate and phosphate) 


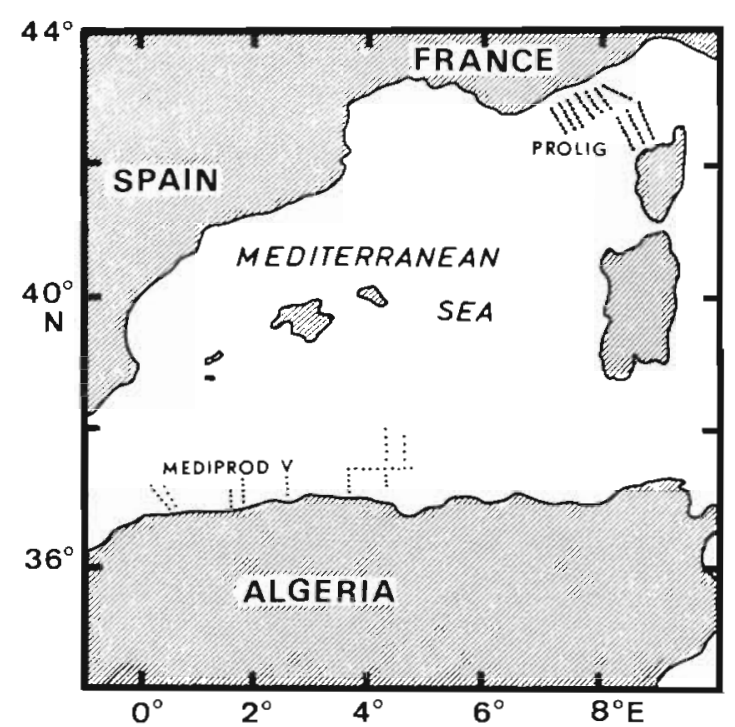

Fig. 1. Sampling stations on the 'Prolig II' cruise in the Ligurian Sea and 'Mediprod V' cruise in the Algerian Basin

were immediately analysed on a Technicon AutoAnalyzer, according to Tréguer \& Le Corre (1975). Chlorophyll measurements were made by fluorimetry on the unfractionated samples (total $\mathrm{chl}$ a) and on the fractionated samples on Whatman GF/F filters, after extraction in pure methanol as described in Raimbault et al. (1988). Fractionated samples were gravity-filtered through $10 \mu \mathrm{m}$ mesh nets, and through 1 or $3 \mu \mathrm{m}$ nuclepore filters ( $47 \mathrm{~mm}$ diameter) by direct filtration at very low pressure ( $\ll 100 \mathrm{~mm} \mathrm{Hg}$ ) as recommended by $\mathrm{Li}$ (1987). For convenience, we adopt the terminology $<10 \mu \mathrm{m} \operatorname{chl} a_{r}<3 \mu \mathrm{m}$ chl $a_{\text {, and }}<1 \mu \mathrm{m}$ chl a defining the chlorophyll measured on samples passing through the $10 \mu \mathrm{m}$ mesh net, and through the $3 \mu \mathrm{m}$ and $1 \mu \mathrm{m}$ nuclepore membranes, respectively, and retained on Whatman GF/F filters. The size limit of each fraction is defined by the stated mesh and pore size of the membranes. Note that the 3 fractions were not always taken simultaneously at each station.

\section{RESULTS}

During early summer, we observed varying vertical hydrological structures resulting from the development of the thermocline and from the mesoscale hydrodynamical features observed along the Algerian coasts (Prieur et al. 1988). For this study, we selected 3 stations located in the same area showing different degrees of seasonal stratification. Although these stations did not systematically represent the variation in phytoplankton vertical size distributions, they are of interest when simultaneously screened and allow direct comparisons. Stn 0 (Fig. 2a) showed a non-

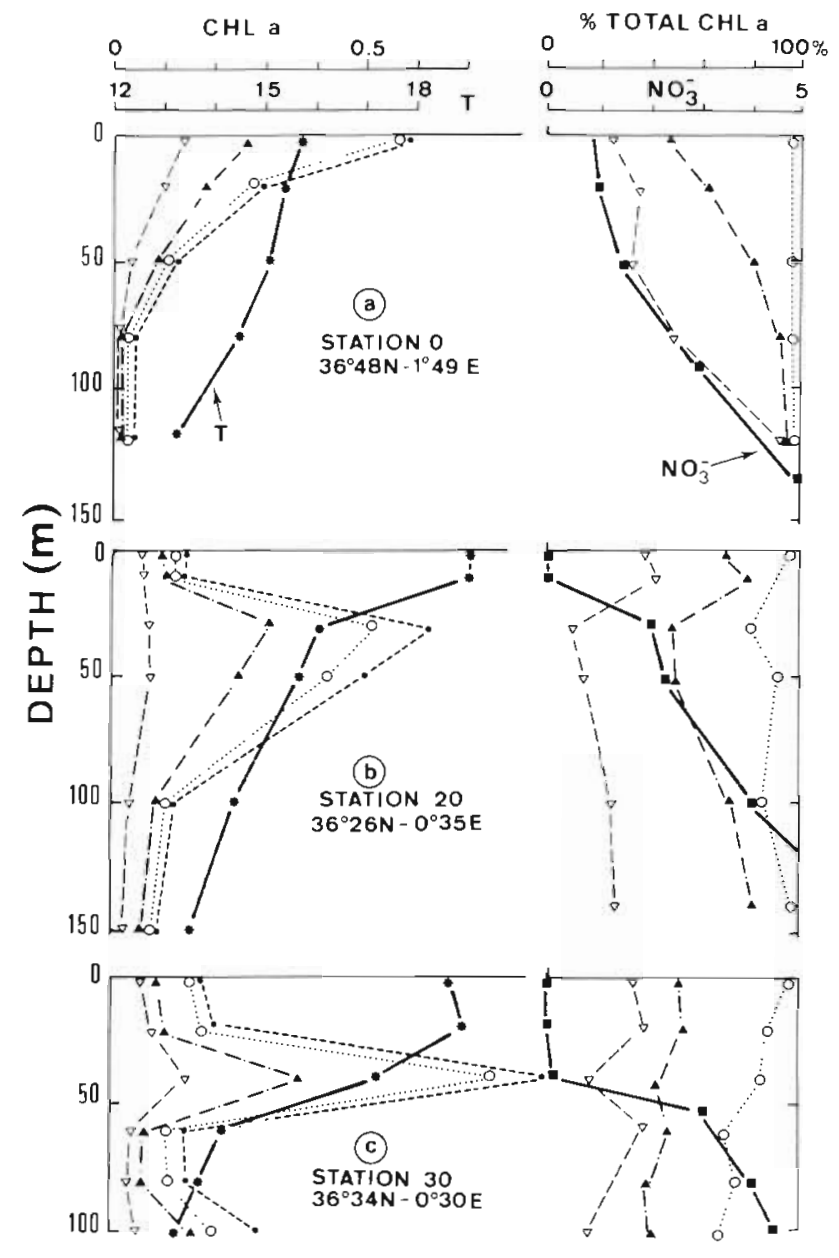

Fig. 2. Typical vertical distributions, from 3 stations in the Algerian Basin, of $(*)$ temperature $\left({ }^{\circ} \mathrm{C}\right)$, (-) nitrate $(\mu M)$ and $(\bullet)$ total chl a $\left(\mu \mathrm{g} \mathrm{I}^{-1}\right)$; distributions of fractionated chl a and percentage of chl $a$ in the $(0)<10 \mu \mathrm{m},(\mathbf{1})<3 \mu \mathrm{m}$ and $(\nabla)$ $<1 \mu \mathrm{m}$ fractions

stratified structure, although slight warming of surface water occurred. Nutrients were present in the surface layer (1.06 $\mu \mathrm{MNO}_{3}^{-}$and $\left.0.12 \mu \mathrm{M} \mathrm{PO}_{4}^{3-}\right)$ and their concentrations increased with depth; the chl a concentration was maximum at the surface $\left(0.57 \mu \mathrm{g} \mathrm{I}^{-1}\right)$ and decreased with depth. This distribution pattern was encountered during the first part of the Mediprod $V$ and Prolig II cruises and in regions of weak upwelling in the Algerian current (Taupier-Letage et al. 1988). At Stn 20 (Fig. 2b), a surface layer with high temperature, nutrient deficiency (nitrate and phosphate were undetectable) and low chl a concentration $\left(0.14 \mu \mathrm{gl}^{-1}\right)$ was observed. A subsurface chlorophyll maximum developed near the thermocline associated with the nitracline. This situation corresponded to the beginning of vertical stratification in early summer. Finally, Stn 30 (Fig. 2c) was characterized by a deeper thermocline and a deeper chlorophyll maximum. The surface layer 
was nutrient-depleted and the chlorophyll maximum was related to the nitrate gradient. In addition to the primary chlorophyll maximum, a deeper secondary maximum was present. This feature was observed at only 6 stations during Mediprod V, and was not typical of the stratified structure.

For the 3 hydrological structures described above, the depth profiles of fractionated chl a and total chl a were similar. This similarity was clearly shown at Stn 30 , where a fractionated chl a maximum coincided with the secondary total chl a maximum. These fractionated or total chl a maxima were found between 25 and $80 \mathrm{~m}$, but were always related to the depth of the top of the nitracline. The percentages of the $<3$ and $<1 \mu \mathrm{m}$ fractions changed throughout the photic zone (Fig. 2), with minimum values being found around the chlorophyll maximum layer, irrespective of the total chl a concentration. Fig. 3 shows vertical distributions of percentages of chl $a$ in the different fractions versus total chlorophyll in relation to the position of the chlorophyll maximum (near the surface, between 10 and $50 \mathrm{~m}$ and below $50 \mathrm{~m}$ ). In all situations the percentage of $<10 \mu \mathrm{m}$ chl a did not fluctuate throughout the water column and was generally higher than $80 \%$. In a non-stratified situation where the chlorophyll maximum stayed near the surface, the percentage of $<1 \mu \mathrm{m}$ and $<3 \mu \mathrm{m}$ were low at the surface and increased with depth, i.e. with the decrease of the total chl a concentration. Pooling all data obtained in the same hydrological situation, the mean percentages of $<1 \mu \mathrm{m}$ and
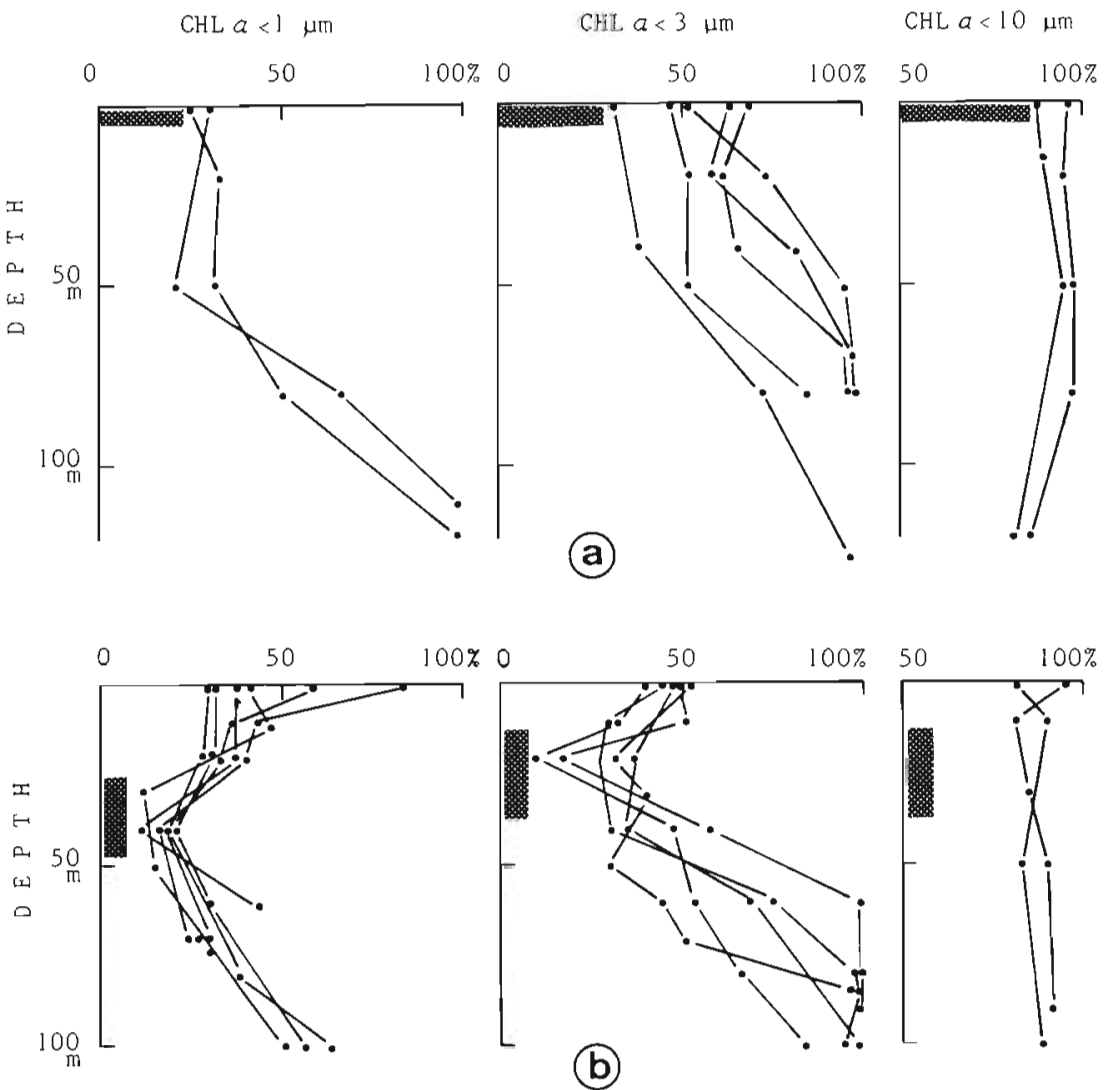

Fig. 3. Examples of vertical distributions of percentages of chl $a$ in the $<1 \mu \mathrm{m}$, $<3 \mu \mathrm{m}$ and $<10 \mu \mathrm{m}$ fractions obtained during the Prolig II and Mediprod V cruises. Shaded areas indicate the position of the total chlorophyll maximum: (a) near the surface; (b) between 15 and 50 $\mathrm{m}_{i}$ (c) below $50 \mathrm{~m}$

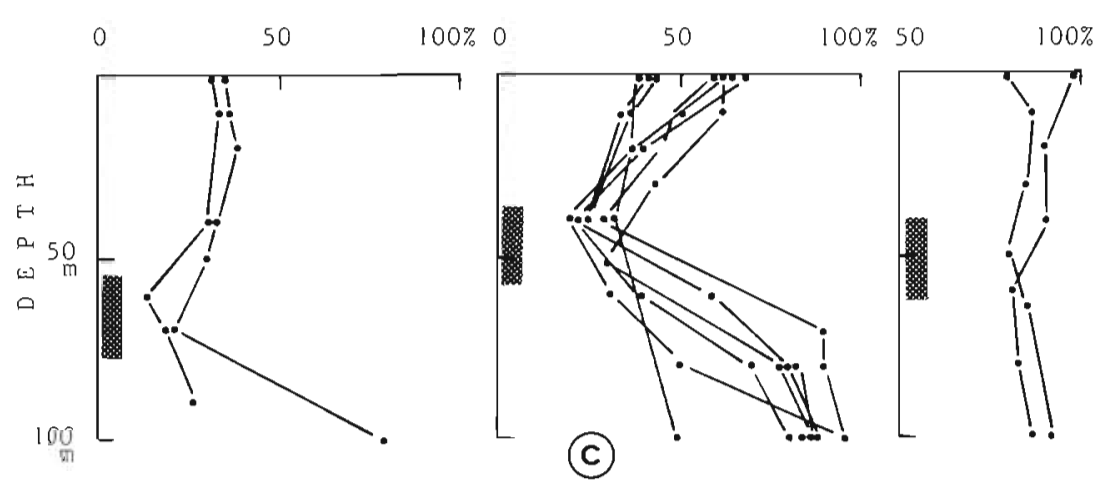


$<3 \mu \mathrm{m}$ chl a in surface waters were, respectively, $22.8 \%$ and $50 \%$ in the Ligurian Sea, and $25 \%$ and $52.8 \%$ in the Algerian Basin. At the bottom of the photic zone, the percentage of $<3 \mu \mathrm{m}$ chl a frequently reached more than $80 \%$, as at Stn 0 (Fig. 2 a), and $<1$ um chl a represented somewhat more than $50 \%$. In stratified structures, the percentages of $<1 \mu \mathrm{m}$ and $<3$ $\mu \mathrm{m}$ chl a were minimum in the chlorophyll maximum layer, and maximum in the deep layer. Percentages of $<3 \mu \mathrm{m}$ chl a higher than $50 \%$ were generally observed

Table 1. Mean values $(\bar{X} \pm S D)$ of chl a percentages in the different size fractions through the photic zone in the Mediterranean Sea, during the season of vertical stratification. Pooled data of Prolig II and Mediprod V cruises obtained with rosette sampler and submersible pump. n: number of samples

\begin{tabular}{|c|c|c|c|}
\hline Sampling layer & $<10 \mu \mathrm{m}$ & $\begin{array}{l}\text { Fraction } \\
<3 \mu \mathrm{m}\end{array}$ & $<1 \mu \mathrm{m}$ \\
\hline $\begin{array}{l}\text { Above the } \\
\text { chlorophyll } \\
\text { maximum }\end{array}$ & $\begin{array}{c}90.71 \\
\pm 8.90 \\
(n=9)\end{array}$ & $\begin{array}{r}53.16 \\
\pm 15.31 \\
(n=74)\end{array}$ & $\begin{array}{r}38.33 \\
\pm 4.97 \\
(n=16)\end{array}$ \\
\hline $\begin{array}{l}\text { In the chlorophyll } \\
\text { maximum layer }\end{array}$ & $\begin{array}{c}82.37 \\
\pm 9.01 \\
(n=15)\end{array}$ & $\begin{array}{r}30.81 \\
\pm 13.59 \\
(n=35)\end{array}$ & $\begin{array}{r}19.27 \\
\pm \quad 4.78 \\
(n=15)\end{array}$ \\
\hline $\begin{array}{l}\text { Below the } \\
\text { chlorophyll } \\
\text { maximum }\end{array}$ & $\begin{array}{r}82.67 \\
\pm 12.03 \\
(n=9)\end{array}$ & $\begin{array}{r}86.59 \\
\pm 15.57 \\
(n=46)\end{array}$ & $\begin{array}{r}60.80 \\
\pm 25.56 \\
(\Omega=13)\end{array}$ \\
\hline
\end{tabular}

in the surface layer and below the chlorophyll maximum layer (Table 1), except, however, at stations where there was a second chlorophyll maximum (data from these stations were not taken into account for mean calculations, in Table 1 ). The $<1 \mu \mathrm{m}$ chl a generally represented less than $50 \%$ of total chl a in the surface nutrient-depleted layer; this percentage decreased to $20 \%$ in the chlorophyll maximum layer and increased again below this depth to more than $50 \%$. The mean value given in Table 1 for the deep layer $(60.8 \%)$ is probably an overestimate because very high percentages of $<1 \mu \mathrm{m}$ chl a $(100 \%)$ tended to occur in some samples collected during continuous vertical profiling.

\section{DISCUSSION}

These observations confirm the extreme small size of chlorophyl-containing particles in the sea, with a predominance of cells $<10 \mu \mathrm{m}$ in the Mediterranean Sea during the spring period. Although the data presented here were collected over a relatively limited time of the year, and although analyses of the 3 different size fractions were not always performed simultaneously on the same sample, a general pattern in the vertical size distribution of phytoplankton is apparent. In the chlorophyll maximum layer, favorable light and nutrient conditions lead to the best growth of all phytoplankton groups, reflected here by the chlorophyll biomass maximum found in each size class (Fig. 2). Although it is well known that the chlorophyll maximum might be due to a shade adaptation of phytoplankton, maximum cell abundance of pico- and ultraplankton was always found in this layer (Furuya \& Marumo 1983b, Glover et al. 1985b, Shapiro \& Guillard 1987). The persistence of these maxima suggests that the mechanisms responsible for their maintenance (reviewed by Cullen 1982) would be the same for all the phytoplankton size groups. Nonetheless the relative importance of each size class changed through the photic zone. Pooling all the data from Fig. 3 and Table 1, we propose a schematic vertical distribution of the percentages of the different size chlorophyll fractions in temperate stratified waters (Fig. 4a). This can be compared to a diagram previously drawn for tropical regions, which were permanently underlain by a thermocline (Herbland et al. 1985; Fig. 4b). The $>10$ $\mu \mathrm{m}$ fraction is always poorly represented (less than 15 to $20 \%$ ) both in tropical and temperate waters, and its distribution throughout the photic zone remains

PERCENTAGE OF TOTAL CHLOROPHYLL
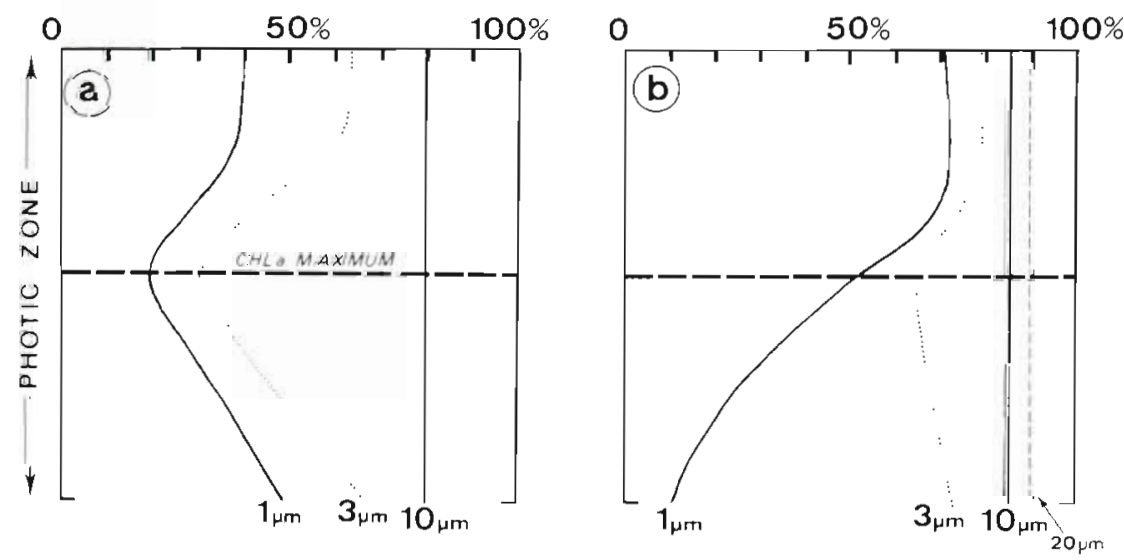

Fig. 4. Schematic and synthetic vertical distribution of the percentage of the different phytoplankton size classes (in terms of chl a) in the euphotic zone, in relation to the depth of the chlorophyll maximum layer associated with the thermocline (horizontal broken line). (a) Mediterranean Sea during the warm season when vertical stratification is established (derived from data presented in Table 1 and stations showing similar hydrological vertical structure). (b) Equatorial Atlantic Ocean (from Herbland et al. 1985) 
roughly constant. The vertical distribution of the $<3 \mu \mathrm{m}$ chl a percentage is generally similar in tropical and temperate waters, exhibiting a subsurface minimum near the nitracline located in the chlorophyll maximum layer, whatever the depth at which nitrate becomes detectable. However, there are some slight differences in numerical values between the 2 oceanic areas; the relative abundance of the $<3 \mu \mathrm{m}$ fraction in the surface layer is less marked in the Mediterranean Sea, and the decrease of this percentage in the chlorophyll maximum layer is more pronounced. Thus, the chlorophyll maximum appears to be due to the best relative development of phytoplankton species passing through a $10 \mu \mathrm{m}$ mesh net but not through a $3 \mu \mathrm{m}$ nuclepore membrane: this size-class is the first to benefit from nutrient supply. The most important regional contrast comes from the $<1 \mu \mathrm{m}$ fraction. In tropical waters this fraction is predominant in the surface layer (up to $70 \%$ ), but its percentage decreases rapidly in the thermocline, reaching a very low value at the bottom of the photic zone $(<10 \%)$. The great decrease of the $<1 \mu \mathrm{m}$ chl $a$ in the deep layer of the tropical waters might be an artefact due to the interference of chlorophyll $b$ in the fluorimetric method (Herbland et al. 1987). In temperate waters however, the $<1 \mu \mathrm{m}$ fraction is not predominant in surface waters $(<40 \%)$, but becomes an important component of the phytoplankton population ( $>50 \%$ ) below the thermocline. These data contrast with those from Arctic waters (Smith et al. 1985), where the percentage of $<1 \mu \mathrm{m}$ chl a showed no vertical variation, in spite of variations of total chlorophyll concentration and temperature. The great predominance of the $<1 \mu \mathrm{m}$ and $<3 \mu \mathrm{m}$ phytoplankton populations, both in the 'high-light/nutrientdeficient' surface layer and in the 'low-light/nutrientrich' deep layer, suggests that pico- and ultraplankton are better adapted to these 'strategic depths' of the photic zone than the nanoplankton, although they are not restricted to these depths. These descriptive data are in agreement with experimental results showing different species of ultraplankton, such as cyanobacteria or eukaryotic phytoplankton with high concentration of chlorophyll $b$, well-adapted for growth under low green light intensities as found in the bottom of the stratified photic zone, where an ample nutrient supply is maintained (Platt et al. 1983, Alberte et al. 1984, Barlow \& Alberte 1985, Glover et al. 1985a, 1986, Fogg 1986). Other small phytoplankton species generally considered as efficient users of erratic nutrient stocks (Perry et al. 1981, Harris 1984, Fogg 1986), can use high light intensities as found in the nutrient-depleted surface layer (Gieskes \& Kraay 1986, Kana \& Glibert 1987). Light, but also nutrient availability, are important for the size distribution of the phytoplankton populations (Herbland et al. 1985). All phytoplankton com- munities serve as a grazing resource, but the grazers are not the same for populations dominated by picoand ultraplankton and for those dominated by nanoplankton (Johnson et al. 1982, Rassoulzadegan et al. 1987). These results should lead us to modify the common concept of the functioning of the pelagic ecosystem. Is the food web the same throughout the water column when important vertical variations in size distribution of phytoplankton occur?

Acknowledgements. This work was supported by the Centre National de la Recherche Scientifique (UA 41) and by the GRECO 34. The authors express their sincere thanks to $\mathrm{L}$. Prieur and N. Garcia for their technical cooperation at sea, and to M. C. Bonin for her help in literature research.

\section{LITERATURE CITED}

Azov, Y (1986). Seasonal pattern of phytoplankton productivity and abundance in nearshore oligotrophic waters of the Levant basin (Mediterranean). J. Plankton Res. 8(1): $41-53$

Alberte, R. S., Wood, A. M., Kursar, T A., Guillard, R. R. L. (1984). Novel phycoerythrin in marine Synechococcus sp. Plant Physiol. 75: 732-739

Barlow, R. G., Alberte, R. S. (1985). Photosynthetic characteristics of phycoerythrin-containing marine Synechococcus sp. I. Responses to growth photon flux density. Mar. Biol. 86: 63-74

Berman, T., Townsend, D. W., El Sayed, S. Z., Trees, C., Azov, Y (1984). Optical transparency, chlorophyll and primary productivity in the Eastern Mediterranean Sea. Oceanological Acta 7 (3): 367-372

Bienfang, P. K. (1984). Size structure and sedimentation of biogenic microparticulates in subarctic ecosystem. $J$. Plankton Res. 6: 985-995

Bienfang, P. K. (1985). Size structure and sinking rates of various microparticulate constituents in oligotrophic Hawaiian waters. Mar. Ecol. Prog. Ser. 23: 143-151

Bienfang, P. K., Szyper, J. P. (1981). Phytoplankton dynamics in the subtropical Pacific Ocean off Hawaii. Deep Sea Res. 28 (A): 981-1000

Bienfang, P. K., Takahashi, M. (1983). Ultraplankton growth rates in a subtropical ecosystem. Mar. Biol. 76: 23-218

Cullen, J. J. (1982). The deep chlorophyll maximum: comparing vertical profiles of chlorophyll a. Can. J. Fish. aquat. Sci. 39: 791-803

Fogg, G. E. (1986). Light and ultraplankton. Nature, Lond. 319: 96

Furuya, J. A., Marumo, R. (1983a). The structure of the plankton community in the subsurface chlorophyll maxima in the Western North Pacific Ocean. J. Plankton Res. 5: 393- 406

Furuya, J. A., Marumo, R. (1983b). Size distribution of phytoplankton in the Western Pacific Ocean and adjacent waters in summer. Bull. Plank. Soc. Japan 30 (1): 21-32

Gieskes, W. W. C., Kraay, G. W. (1986). Floristic and physiological differences between the shallow and the deep nanoplankton community in the euphotic zone of the open tropical Atlantic revealed by HPLC analysis of pigments. Mar. Biol. 91: 567-576

Gieskes, W. W. C., Kraay, G. W., Baars, H. A. (1979). Current ${ }^{14} \mathrm{C}$ methods for measuring primary production: gross 
understimates in oceanic waters. Neth. J. Sea Res. 13: $58-78$

Glover, H. E., Phinney, D. A., Yentsch, C. S. (1985a). Photosynthetic characteristics of picoplankton compared with those of larger phytoplankton populations, in various water masses in the Gulf of Maine. Biol. Oceanogr. 3: 222-248

Glover, H. E., Smith, A. E., Shapiro, L. (1985b). Diurnal variations in photosynthetic rates: comparisons of ultraplankton with a larger phytoplankton size fraction. J. Plankton Res. 7: $519-535$

Glover, H. E., Keller, M. D., Guillard, R. R. L. (1986). Light quality and oceanic ultraphytoplankters. Nature, Lond. 319: $142-143$

Harris, G. P. (1984). Phytoplankton productivity and growth measurements: past, present, future. J. Plankton Res. 6 (2): $219-237$

Herbland, A., Lebouteiller, A. (1981). The size distribution of phytoplankton and particulate organic matter in the Equatorial Atlantic Ocean, importance of ultraseston and consequences. J. Plankton Res. 3 (4): 659-673

Herbland, A., Lebouteiller, A., Raimbault, P. (1985). Size structure of phytoplankton in the Equatorial Atlantic Ocean. Deep Sea Res. 32 (7): 819-836

Herbland, A., Lebouteiller, A., Raimbault, P. (1987). Does the nutrient enrichment of the equatorial influence the size structure of phytoplankton in the Atlantic Ocean. Oceanological Acta, $\mathrm{N}^{\circ} \mathrm{sp}$. Proceedings international Symposium on Equatorial vertical motion, Paris 6-10 May 1985, p. $115-120$

Johnson, P. W., Xu, H. S., McN Sieburth, J. (1982). Utilization of chroococcoid cyanobacteria by marine zooplankters but not by calanoid copepods. Ann. Océanogr., Paris 58: 297-308

Joint, I. R., Owens, N. J. P. and Pomeroy, A. J. (1986). The seasonal production of picoplankton and nanoplankton in. the Celtic Sea. Mar. Ecol. Prog. Ser. 28: 251-258

Joint, I. R., Pomeroy, A. J. (1983). Production of picoplankton and small nanoplankton in the Celtic Sea. Mar. Biol. 77 : $19-27$

Kana, T. M. and Glibert, P. M. (1987). Effect of irradiance up to $200 \mu \mathrm{E} \mathrm{m}^{-2} \mathrm{~s}^{-1}$ on marine Synechococcus WH 7803. I. Growth, pigmentation and cell composition. Deep Sea Res 34 (4): $479-496$

Li, W K. W. (1987). Experimental approaches to field measurements: methods and interpretation. Bull. Can. Fish aquat. Sci. 214: 251-286

Li, W. K. W., Subba Rao, D. W., Harrison, W G., Smith, J. C.,
Cullen, J. J., Irwin B., Platt, T. (1983). Autotrophic picoplankton in the tropical Ocean. Science 219: 292-295

Murphy, L. S., Haugen, E. M. (1985). The distribution and abundance of phototrophic ultraplankton in the North Atlantic. Limnol. Oceanogr. 30: 47-58

Perry, M. J., Talbot, M. C., Alberte, R. S. (1981). Photoadaptation in marine phytoplankton: response of the photosynthetic unit. Mar. Biol. 62: 91-101

Platt, T., Subba Rao, D. W., Irwin, B. (1983). Photosynthesis of picoplankton in the oligotrophic ocean. Nature, Lond. 301 702-704

Prieur, L., Raimbault, P., Taillez, D. (1988). Very high biomass of phytoplankton in a frontal zone near the Algerian coasts at $4^{\circ} 40 \mathrm{E}$. WMCE Newsletter 11: 65

Raimbault, P., Rodier, M., Taupier-Letage, I. (1988). Size fraction of phytoplankton in the Ligurian Sea and the Algerian Basin (Mediterranean Sea): size distribution versus total concentration. Mar. Microb. Food Webs. (in press)

Rassoulzadegan. F., Laval Peuto, M., Sheldon, R. W (1987) Partitioning of the food ration of marine ciliates between pico and nanoplankton. Hydrobiologia (in press)

Saijo, Y., Takesue, K. (1965). The use of cage cultures in studies of the biochemistry and ecology of marine phytoplankton. Oceanogr. mar. Biol. A. Rev. 16: 81-106

Shapiro, L. P., Guillard, R. R. L. (1987). Physiology and ecology of the marine eukariotic ultraplankton. Can. J. Fish. aquat. Sci. $214 ; 371-389$

Smith, J. C., Platt, T., Li, W K. W., Horne, E. P. W., Harrison W. G., Subba Rao, D. U., Irwin, B. P. (1985). Arctic marine photoautotrophic picoplankton. Mar. Ecol. Prog. Ser. 20: 207-220

Takahashi, M., Bienfang, P. K. (1983). Size structure of phytoplankton biomass and photosynthesis in subtropical Hawaiian water. Mar. Biol. 76: 203-211

Takahashi, M., Kikuchi, K., Hara, Y. (1985). Importance of picocyanobacteria biomass (unicellular, blue-green algae) in the phytoplankton population of the coastal water off Japan. Mar. Biol. 89: 63-69

Taupier-Letage, I., Raimbault, P., Millot, C. (1988). Biological consequences of the Algerian current mesoscale activity. WMCE Newsletter 11: 63

Treguer, P., Le Corre, P. (1975). Manuel d'analyses des sels nutritifs dans l'eau de mer, (utilisation de l'autoanalyseur II Technicon). 2nd edn. Laboratoire d'Océanographique chimique, Univ. de Bretagne Occidentale, Brest

Waterbury, J. B., Watson, S. W., Guillard, R. R. L., Brand, L. E. (1979). Widespread occurrence of an unicellular marine plankton cyanobacteria. Nature, Lond. 277: 293-294

This article was submitted to the editor $;$ it was accepted for printing on April 12, 1988 